\title{
Are Generalized Reduced Cerebrospinal Fluid Dynamics and Optic Nerve Sheath Compartmentation Sequential Steps in the Pathogenesis of Normal-Tension Glaucoma? [Letter]
}

\section{Peter Wostyn (D)}

Department of Psychiatry, PC SintAmandus, Beernem, Belgium
Correspondence: Peter Wostyn Department of Psychiatry, PC SintAmandus, Reigerlostraat 10, Beernem, 8730, Belgium

Tel + 32-472713719

$\mathrm{Fax}+32-50-819720$

Email wostyn.peter@skynet.be

\section{Dear editor}

I read with great enthusiasm the recently published article in Eye and Brain by Pircher et $\mathrm{al}^{1}$ reporting a higher concentration of lipocalin-type prostaglandin D synthase (L-PGDS) in the perioptic subarachnoid space (SAS) compared to the concentration in the lumbar SAS in a group of normal-tension glaucoma (NTG) patients with optic nerve $(\mathrm{ON})$ sheath compartmentation. I greatly appreciate the tremendous contributions Prof. Killer and his team have made to our understanding of perioptic cerebrospinal fluid (CSF) flow dynamics and their role in glaucoma pathogenesis, and I am grateful to the authors for sharing their new work with the scientific community. I would appreciate the opportunity to comment on their discussion of the L-PGDS levels in the lumbar SAS.

Pircher et $\mathrm{al}^{1}$ found significantly higher lumbar CSF levels of L-PGDS in their cohort of NTG patients with ON sheath compartmentation when compared to other studies on L-PGDS in healthy subjects. Reference values for L-PGDS concentrations in normal human lumbar CSF are $16.6 \pm 3.6 \mathrm{mg} / \mathrm{L} .{ }^{2}$ Remarkably, compared with these normal values, the mean L-PGDS concentration in the lumbar CSF was significantly elevated in their group of NTG patients $(24 \pm$ $8 \mathrm{mg} / \mathrm{L}$ ). ${ }^{1}$ This finding is consistent with a hypothesis previously proposed by my colleagues and me, according to which NTG, in at least some cases, may result from CSF circulatory dysfunction. ${ }^{3}$ We speculated that changes in the CSF circulation and the subsequent decrease in overall CSF turnover could ultimately result in reduced neurotoxin clearance in the SAS surrounding the $\mathrm{ON}$ and lead to ON sheath compartmentation. ${ }^{3}$ Indeed, it is conceivable that the reduced neurotoxin clearance along the ONs might have an influence on meningothelial cells, eventually leading to increased proliferation and CSF compartmentation. ${ }^{3}$ The accumulation of biologically active molecules in this blocked ON compartment might further produce a toxic effect on the ON and lead to glaucomatous damage. ${ }^{4}$ According to the above hypothesis, generalized reduced CSF dynamics and ON sheath compartmentation could then be seen as sequential steps involved in the development of $\mathrm{NTG}^{3}{ }^{3}$ To assess whether there 
is evidence in support of this hypothesis, in our 2013 paper, we proposed that L-PGDS concentrations in lumbar CSF could be compared between NTG patients and control subjects. ${ }^{3}$ A significantly higher lumbar CSF L-PGDS concentration in NTG patients compared with controls would add support to our hypothesis of CSF circulatory failure, given the reported increase of L-PGDS concentration in lumbar CSF in case of decreasing CSF flow rate. ${ }^{3}$

Obviously, further studies are needed to elucidate whether changes in the CSF circulatory system may play a role in the pathogenesis of NTG. If confirmed, disruptions in CSF flow during aging, and neurological diseases involving impaired CSF dynamics would be expected to predispose individuals to the development of NTG. Some cases of NTG might then actually be the expression of generalized impaired CSF dynamics in natural brain aging and CNS diseases such as Alzheimer's disease (AD). In this respect, it is interesting to note that several studies demonstrated a positive association between NTG and $\mathrm{AD}^{5}$

\section{Disclosure}

The author reports no conflicts of interest in this communication.

\section{References}

1. Pircher A, Neutzner A, Montali M, et al. Lipocalin-type prostaglandin D synthase concentration gradients in the cerebrospinal fluid in normal-tension glaucoma patients with optic nerve sheath compartmentation. Eye Brain. 2021;13:89-97. doi:10.2147/EB. S297274

2. Tumani H, Reiber H, Nau R, et al. Beta-trace protein concentration in cerebrospinal fluid is decreased in patients with bacterial meningitis. Neurosci Lett. 1998;242(1):5-8. doi:10.1016/S0304-3940(98)00021-4

3. Wostyn P, De Groot V, Van Dam D, Audenaert K, De Deyn PP. Senescent changes in cerebrospinal fluid circulatory physiology and their role in the pathogenesis of normal-tension glaucoma. Am J Ophthalmol. 2013;156(1):5-14. doi:10.1016/j.ajo.2013.03.003

4. Killer HE, Jaggi GP, Flammer J, Miller NR. Is open-angle glaucoma caused by impaired cerebrospinal fluid circulation: around the optic nerve? Clin Exp Ophthalmol. 2008;36(4):308-311. doi:10.1111/ j.1442-9071.2008.01735.x

5. Chen YY, Lai YJ, Yen YF, et al. Association between normal tension glaucoma and the risk of Alzheimer's disease: a nationwide population-based cohort study in Taiwan. BMJ Open. 2018;8(11):e022987. doi:10.1136/bmjopen-2018-022987

Dove Medical Press encourages responsible, free and frank academic debate. The content of the Eye and Brain 'letters to the editor' section does not necessarily represent the views of Dove Medical Press, its officers, agents, employees, related entities or the Eye and Brain editors. While all reasonable steps have been taken to confirm the content of each letter, Dove Medical Press accepts no liability in respect of the content of any letter, nor is it responsible for the content and accuracy of any letter to the editor.

Eye and Brain

\section{Dovepress}

\section{Publish your work in this journal}

Eye and Brain is an international, peer-reviewed, open access journal focusing on clinical and experimental research in the field of neuroophthalmology. All aspects of patient care are addressed within the journal as well as basic research. Papers covering original research, basic science, clinical and epidemiological studies, reviews and

Submit your manuscript here: https://www.dovepress.com/eye-and-brain-journal evaluations, guidelines, expert opinion and commentary, case reports and extended reports are welcome. The manuscript management system is completely online and includes a very quick and fair peerreview system, which is all easy to use. Visit http://www.dovepress. com/testimonials.php to read real quotes from published authors. 